\title{
Forest Replacement in Brazil: A Fundamental Policy for Forestry
}

\author{
Athila Leandro de Oliveira ${ }^{1}$ (1) 0000-0002-9455-8237 \\ Luís Antônio Coimbra Borges ${ }^{2}$ (D) 0000-0003-0344-5008 \\ Marcondes Geraldo Coelho Junior ${ }^{1}$ (1) 0000-0002-4352-9321 \\ Dalmo Arantes de Barros ${ }^{2}$ (1) 0000-0002-9551-560X \\ Luiz Moreira Coelho Junior ${ }^{3}$ (1) 0000-0001-5528-7799
}

\begin{abstract}
Forest replacement is a public policy consisting of a set of measures that ensure the continuity of forest raw material supply to the consumers of native species. It is currently required through Art. 33 of the Federal Law 12,651/2012. Thus, this study aimed to characterize the main legislations and facts related to the forest replacement policy, addressing their responsible bodies and indicating their contributions to the forest sector, based on an extensive bibliographical and documentary research. Three federal bodies stood out as being responsible for such policy: INP, IBDF, and Ibama; being the responsibility of the third one shared with similar state agencies. The planted area was significant, especially during the period in which the IBDF was the responsible body, due to its encouraging performance and the incentives in force. We observed there are still problems related to transparency and implementation effectiveness due to the lack of joint actions between stakeholders and the incipient technical assistance.
\end{abstract}

Keywords: forest management, forest law, reforestation.

\section{INTRODUCTION}

The Brazilian forest sector stands out for the efficiency in the development of forest plantations in comparison with the world scenario. The area of planted forest massifs accounts for 7.84 million hectares, considered small compared with the total of natural forests, which cover approximately 485 million hectares, with 53\% of the areas located in rural properties (FAO, 2015; Soares-Filho et al, 2014). Despite covering small areas, the forest plantations can supply about $90 \%$ of the wood produced for industrial purposes and are responsible for $6.2 \%$ of the industrial GDP in Brazil (IBÁ, 2017).

Historically, Brazil has had difficulties to expand forest plantations in a lasting way (Moreira et al., 2017). In this context, when analyzing the period from 1970 to 2006 , a $170 \%$ increase in the national area of woody plantations is observed, which became the fourth culture with the largest planted area in the country, only behind soybeans, corn, and sugarcane (IBGE, 2007).
The lack of expressiveness in terms of planted forest areas is related to the forest policies in force throughout history. The prioritization of forest reserves and the criticism to pine and eucalyptus plantations were noteworthy by the end of the 1940s (Norder, 2017). This conception began to change in the middle of the last century and culminated with the publication of the old Forestry Code, Law 4,771/1965, from which public policies for reforestation gained importance at a national level, such as the forest replacement and the maintenance of supply forests by large consumers of forest raw material (Gomes Neto \& Léda, 2009).

Forest replacement is a public policy aimed to compensate for the volume of raw material extracted from natural vegetation through forest plantations for stock regulation or forest cover recovery (Freire, 2009). Obligation, linked to the right to suppress certain forest massifs can be, fulfilled by carrying out forest plantations equivalent to the volume consumed or by paying in forest credits equivalent to the value of the forest that should have been planted, usually deposited in

\footnotetext{
${ }^{1}$ Universidade Federal Rural do Rio de Janeiro (UFFRJ), Rio de Janeiro, RJ, Brasil

${ }^{2}$ Universidade Federal de Lavras (UFLA), Lavras, MG, Brasil

${ }^{3}$ Universidade Federal da Paraíba (UFPB), João Pessoa, PB, Brasil
} 
an account managed by the State Environmental Agency (OEMA) (Soares \& Aguiar, 2017).

States such as Mato Grosso, Minas Gerais, Pará, Rondônia, and São Paulo have regulated this policy in order to adapt it to the local context (Vianna et al., 2013). Depending on the state where the native forest raw material was consumed, the respective collection regulations should be considered. In Minas Gerais, for example, the collection is established by the State Law 20,922/2013 (Minas Gerais, 2013).

Minas Gerais is of great importance for the national forest sector. This state has the largest area of plantations of exotic species, approximately $1 / 4$ of all eucalyptus, and is also the largest consumer of this raw material (IBÁ, 2017). This importance, in terms of forest massifs planted with exotic cultures, is observed since the Tax Incentives Law establishment, between 1966 and 1988 , in which these plantations were deducted from taxes, but were also related to forest replacement. Given this context, forest districts were established to meet programs such as the Paper and Pulp National Program and the Plant Charcoal Plan for steel mills (Bacha, 1991).

Forest Replacement is an important public policy for the industry, since, aiming at the formation of a forest stock to supply the industry, it contributes to preserving the environment by reducing the pressure on massifs of native forest. It has also been used to restrict the consumption of products of native origin, requiring plantations of areas larger than the equivalent in consumption (Sabbag, 2011).

To recognize the importance of the use of native raw material and forest replacement is mandatory. The main legislation and facts related to forest replacement were addressed in this study, highlighting the responsible bodies and the main forms of payment, contextualizing and indicating the contributions of the forest replacement policy for the forest sector at a national level.

\section{FOREST REPLACEMENT: STATE OF THE ART}

Historically, man has always used natural resources. However, concerns for the impacts caused by anthropogenic activities have left their mark during the last decades (Griggs, 2013). In the 1950s, a movement called "environmentalism of scientists" emerged and some events have been held ever since, such as the United Nations Conference on the Human Environment in Stockholm, 1972; the Brundtland Report, 1987; the United Nations Conference on Environment and Development, also known as "Rio 92"; and the Sustainable Development United Nations Conference ("Rio + 20") in 2012 (Antunes et al., 2017; Lopes et al., 2017). All these events discussed issues on sustainable development, which influenced several public policies around the world, indirectly or through international agreements.

The forest replacement stands out in the forest sector among all the policies aiming at the sustainable development. At a national level, it was once the responsibility of the Pine National Institute (INP), of the Brazilian Institute for Forest Development (IBDF), and it is currently the responsibility of the Brazilian Institute of Environment and Renewable Natural Resources (Ibama). This commitment is now shared with similar state agencies (Figure 1).

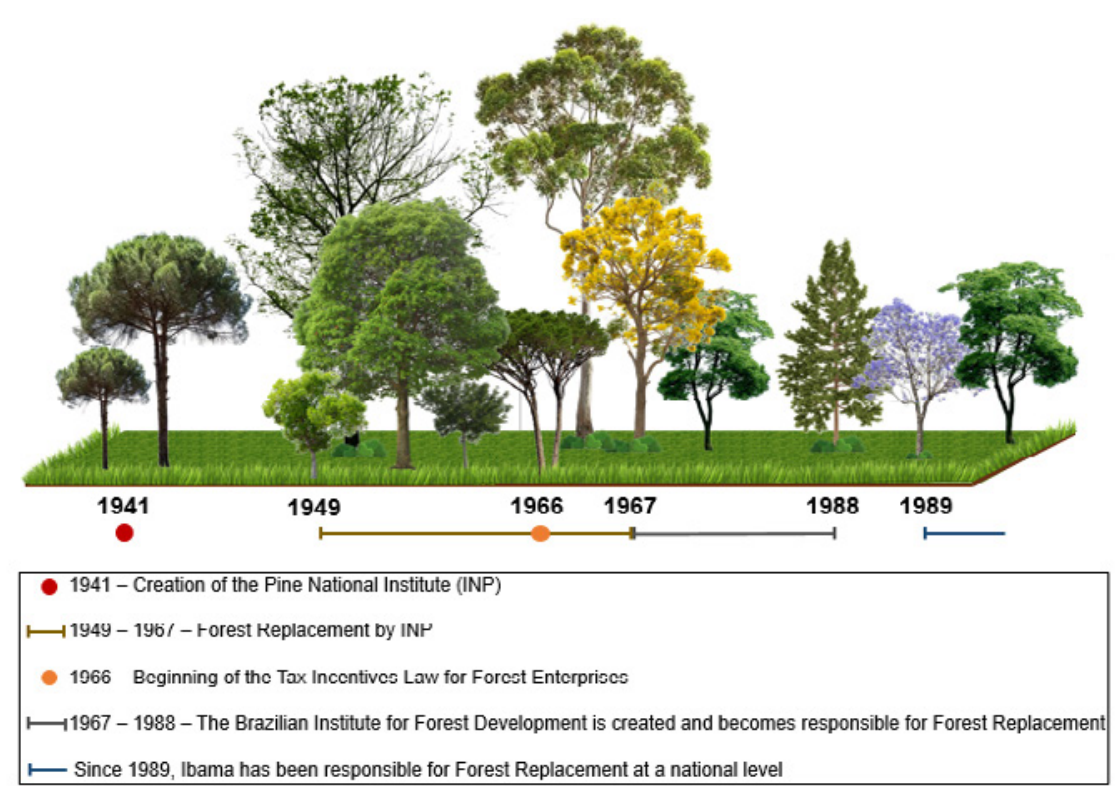

Figure 1. Historical line highlighting the main periods and bodies responsible for the Forest Replacement. 
An extensive bibliographic review describing the succession of the bodies highlighted in the figure above was necessary to carry out this study, showing the differences in the practice of forest replacement in each period, and pointing out how this public policy influenced the current areas of forest plantations of exotic species.

\subsection{Initial theoretical proposals}

The first concerns about what is considered the embryo for the forest replacement in Brazil emerge in 1821. During this period, wood was the main source of energy. However, this raw material was not available in the large centers. In this context, when José Bonifácio de Andrada e Silva, then a counselor of the kingdom, came back from his studies in Europe, he recommended forest replacement measures in a letter sent to the deputies of São Paulo (Silva, 1821).

The suggestion of Andrada e Silva had no practical effects. Deforestation continued, especially where livestock activities were held more intensively, close to urban centers, due to the great importance of wood as an energy supplier. Only after the end of the 19th century, with the increase in the use of hydroelectricity and petroleum, there was a decreasing trend in the use of charcoal and firewood as an energy source in domestic consumption (Martins, 2011).

The domestic consumption of forest energy sources decreased whereas industrial demand increased, as the expansion of urbanization and economy increased the number of steel mill kilns, bakeries, ceramics, civil construction, among others (Furtado et al., 2012).

Considering industrial and domestic purposes, the total consumption of firewood and charcoal in the early 20th century increased. For this reason, the defense of forests gained a strategic dimension (Fonseca, 2008; Martins, 2011). In this period, the first forest monocultures of exotic species of the genus Eucalyptus were introduced by the Railway Paulista Company in 1904, and the conifers (Pinus) by the São Paulo Improvements Company in 1922 (CSS, 2009).

In 1922, President Arthur Bernardes advocated the establishment of forest and hortos florestais (forest gardens) reserves and the promotion of forestry (Martins, 2011), inspired by the forest policies of the United States, Australia and Canada.

From 1930, Kengen (2001) noticed that the forest policy underwent deeper changes. He highlighted the reorganization of the Brazilian Ministry of Agriculture, as well as the Plant Production Promotion Service, the creation of a Section for Reforestation and Colonization, integrated with the Ministry of Agriculture, and the creation of the first Forest Code and the Pine Instituto (Kengen, 2001).
In 1934, the first Forest Code was published (Federal Decree 23,973), which introduced to the Brazilian legislation the notion of reserved area, recognizing three basic categories: National Park, National, State and Municipal Forests, and Protected Forests, based on the US forest model of the late 19th century (Madeira Filho, 2002).

The importance of Decree 23,973, regarding the replacement, is due to the fact it was the first one to actually establish an obligation analogous to forest replacement, since, by allowing the intensive exploitation of forests, seedlings of the same species had to be planted:

Art. 48. Intensive forest exploitation is understood as that subjected only to the restrictions expressly established by the competent forest bureau, in accordance with this code. Art. 49. In the exploitation of forests of homogeneous composition, the cutting of the trees will have to be done without opening clearings in the forest massif.

Single paragraph. The trees felled, except those that are already being renewed by sprouting, will be replaced by seedlings of the same species or by another forest essence judged preferable, duly selected, always with the spacing required by the technique (Brasil, 1934).

In 1945, Brazil was in a development model that privileged industrial and urban activities. This fact explains why the Federal Government did not allocate resources to its environmental institutions, hindering the compliance with what was established in the Forest Code of 1934 (Bacha, 2004).

The forest chain in the south of the country differed in this context. Gonçalves (2006) pointed out that forest plantation activities were mainly related to Brazilian pine, yerba mate and rubber until the 1940s. These markets were regulated by Institutes that intermediated the State and the private sector, partially giving in to the Forest Service of the Brazilian Ministry of Agriculture and to the Forest Departments linked to the State Departments of Agriculture.

\subsection{Forest replacement by the Pine National Institute}

The Pine National Institute (INP) was an agency created in the "Era Vargas" in 1941, aimed to "regulate the installation of new sawmills and factories for box production and wood beneficiation"; thus, it also regulated the raw material, the Brazilian pine (Araucaria angustifolia), according to the interest of exporters from the producing and benefiting states: São Paulo, Paraná, Santa Catarina and Rio Grande do Sul (Gelis Filho, 2006). On the other hand, this Institute had little activity in other states, even 
in Minas Gerais, which already had an expanding steel sector and a significant use of charcoal.

The INP created the first standardization related to forest replacement, the Resolution 101/1949. Forest exploitation was organized in this resolution; however, it was little related to sustainable management. The obligation to replace should be fulfilled through no-tillage, using the same species, or paying the INP the corresponding planting value. The Institute was also responsible for the management of resources and payments (INP, 1950).

According to the text of the abovementioned resolution:

Art. 19 - The cutting of trees in yield forest requires subsequent reforestation, using trees of the felled forest species or others of economic value, in the proportion determined by the competent authority (INP, 1950).

Since its adoption, this resolution has been responsible for the planting, which was carried out in the National Forests, and for cutting permission. However, the activities carried out by the INP were restricted to the states of the Southern region and São Paulo. States such as Minas Gerais, even with a significant use of forest raw material due to the steel sector, had no promotion of plantations by the INP and, therefore, the government of Minas Gerais had the initiative of creating an incentive agency for the sector: The State Institute of Forests (IEF) (Gonçalves, 2006; Sabbag, 2011).

Concern over forest stocks reflected a desire of the civil and academic community for the protection of forests worldwide, resulting in publications such as those in the Sixth Period of Sessions of the FAO Conference in 1951. The Brazilian Foundation for Nature Conservation (FBCN) and the Brazilian Silviculture Society (SBS) stood out in Brazil. The first one was the pioneer of the Brazilian Non-Governmental Organizations, aimed to discuss forest problems; and the second one came to represent the political organization of the forest sector outside the governmental sphere; both of them pressured the government for incentives to the creation of yield forests (Hoeflich et al., 2007; Pereira, 2002).

This awareness of forest use and conservation resulted in greater pressure on forestry companies to maintain stocks of yield forests from plantations. However, the plantations, even with the forest replacement policy, were still limited. Until 1965, when the INP was still responsible for forest replacement, the area of reforestation was little more than one million hectares, almost eight times smaller than it is today (Bacha, 2008, IBÁ, 2017).

The forest replacement plantings during this period occurred mainly in National Forests and, as commented above, were restricted to the South region and São Paulo.
Thus, Sabbag (2011) reports reforestation plantings with Araucaria angustifolia, Paraná pine, and other species of the genus Pinus. However, this author noted that the financial resources for these plantings were not well defined and that it was not possible to distinguish which ones were obtained by other means of collection performed by the Institute.

\subsection{Forest replacement by the Brazilian Institute for Sustainable Development, during the Fiscal Incentives Law}

Through the Forest Law 4,771/1965, we observe the legislator's concern for the sustainable use of the property, protecting environmentally fragile areas and allowing the suppression for an alternative use of the land. Thus, the law ensured the opening of new areas for the economic use and for the formation of a source of native raw material (Borges \& Rezende, 2011). Sustainable use through the management of native forests and the maintenance of own forests are the basis for conservation, which is the objective of the law.

A policy of incentives for forest production was implemented (Law 5,106/1966) to promote the planting of forests to self-supply of industries. This incentive consisted of the exemption of income tax to those who performed the planting forests and the possibility of using it as payment for forest replacement. The purpose of these incentives was to promote large-scale planting, to boost the use of species of the genera Eucalyptus and Pinus, and create "Forest Districts" for forest-industrial integration (Pereira, 2002).

The Brazilian Institute for Forest Development (IBDF) was created in 1967, combining functions of the Department of Renewable Natural Resources, the National Institute of Mate, and the INP, which until then had worked in parallel (Sabbag, 2011). Thus, the IBDF had an ambitious assignment: manage all the protected areas in the country, being responsible for the compliance with the Forest Code and for the rational use of renewable resources (Medeiros, 2006). Under its responsibility, the planting of forests from the Tax Incentives Law in the late 1970s had already reached at least 200,000 ha/year (Bacha, 2008).

According to Sabbag (2011), the IBDF established standards, but the parameters of conversion and collection were the same as those of the extinct INP. It also enabled the payment by collection through the "Forest Fund of Mandatory Replacement" (Ordinance 2919/1972). By paying this fund, the company passed the obligation of planting to the environmental body, which would manage the financial resources coming from a payment that would be equivalent to what would be spent if the company did the planting itself. This modality is not considered a tax because taxes can only 
be created by law in one of the three government spheres: Union, States or Municipalities (Brasil, 1988). However, payments like this may result in the use of resources for other purposes, failing to promote forest plantations.

The reforestation promoted by the Forest Incentives Law provided for the creation of forest districts, but it did not develop similarly throughout Brazil (Brasil, 1976). States with higher consumption, which had already the obligation of replanting forests, used many incentives. Minas Gerais stood out with $41 \%$ of the planting carried out throughout the country, which started with forest stands implemented until 1973 (Bacha, 1991).

In the early 1980s, Brazil took a major step towards environmental protection by structuring bodies and entities. There was a decentralization of the responsibilities for environmental defense between the Union, States, Federal District, Municipalities and Foundations established by the Public Power through the creation of the Environment National System (Sisnama). Since then, the IBDF was maintained as a sectoral body and state agencies became sectional bodies (Brasil, 1981).

The IBDF was responsible for the tax incentives policy granted to forest enterprises until 1988 when it was finalized through Federal Law 7,714/1988. At the end of this period, Brazil had 6.2 million hectares of forest plantations; 5 million more than it had initially (Bacha, 2008).

Minas Gerais was the state that stood out the most in the period in which the incentives law was in force. Especially, the North of Minas Gerais, where there were inexpensive rural properties (below the market price) with production potential and belonging to the region of the Superintendence for the Development of the Northeast Region (Sudene), near the steel mill centers in the Vale do Rio Doce (Gonçalves, 2006). The state always stood out in the steel sector and so continued during its expansion. The number of companies in the steel sector increased by $291 \%$ between 1970 and 1985 , charcoal consumption doubled from 3 to 6 million tons, most of which coming from native forest (Bacha, 2001).

The use of natural forests persisted and the vegetation cover decreased in the regions of high production due to steel mill development in Minas Gerais and the high consumption of wood, according to Campos \& Chagas (2012). These authors report that this lower stock in the Southeast region, together with a practically unlimited supply of natural forests in the North region, supported by tax incentives from the Superintendence for the Development of the Amazon (Sudam) and Sudene, contributed to the guseiras (companies that turn the ore into pig iron) development in Marabá (Pará state) and Açailândia (Maranhão state), making them the second major national steel mill center. This region became propitious for this activity due to its location along the Carajás railroad and in an area with a high concentration of iron (Monteiro, 1998).

The use of short-fiber species such as eucalyptus was one of the challenges that, once overcome, enabled the expansion of the pulp sector in Brazil. However, the sector was significantly boosted through the tax incentives law (Bacha, 1991). During this period, the Brazilian Development Bank (BNDES), directed the incentives in planting to factories with a minimum capacity of 100 tons/day (BNDES, 1991) through decision 196/68. This measure reconfigured the market and the companies, from which big companies were benefited (Hilgemberg \& Bacha, 2011).

The first Paper and Pulp National Program was also launched in the 1970s, through which the BNDES played a fundamental role in the consolidation of the pulp and paper sector. Moreover, Brazil began to gain importance in the international market due to the low-priced excess supply and the recognition of the quality of the eucalyptus short-fiber pulp. In this context, the importance of forest massifs was also noted in other states such as Southern Bahia and São Paulo (Montebello \& Bacha, 2013).

Consumption of wood from natural forests was high, even with the plantations. In 1974, for example, $78.4 \%$ of the total consumption of roundwood, which comprises the wood used as charcoal, firewood, and wood in logs, came mainly from forest of native species in the Northern region of Brazil (Bacha, 2001).

The number of forestry establishments increased from 4,294 in 1960 to 15,263 in 1985 due to the investments (Bacha, 1995). The profile of properties with forest plantations was different; the properties were higher than the others, with 359 ha on average, whereas the area overall average of the Brazilian rural properties was 72 ha (Bacha, 2001).

In general, the low land value was a motivating factor for choice and many of these plantations had no satisfactory growth (Bacha, 2001). They did not stand out for the wood quality and had low productivity, on average $15 \mathrm{~m}^{3} /$ ha/year, evolving to about $35 \mathrm{~m}^{3} / \mathrm{ha}$ /year in the final years of the 1980 s (Bacha, 2001). Currently, $35 \mathrm{~m}^{3} / \mathrm{ha} /$ year is a common productivity, reaching up to $55 \mathrm{~m}^{3} / \mathrm{ha} /$ year (IBÁ, 2017; SBS, 2008).

The data recorded at that time are not only due to the soil quality, but also to the precarious technology and genetic improvement, in comparison with those currently available. Nevertheless, this forest base was important for the current context, in terms of planting area (Bacha, 2004).

Forest districts created in areas with low potential for consumption were also developed, erroneously in terms of strategy. For example, plantations in the state of Mato Grosso do Sul (361,754 ha) and in Goiás (116,975 ha) regressed due to the lack of a consumer market and their areas were used 
for other purposes, and the wood was sold at prices lower than the market price by distant companies (Sabbag, 2011).

The IBDF was also extinguished due to the end of the tax incentives law for forest enterprises, ending an era, in which the forest plantations had the highest boost in the history of the country; part of these plantations had resulted from forest replacement. Some of the IBDF assignments, such as the responsibility for the forest replacement policy management, were passed to its successor body: the Brazilian Institute for the Environment and Renewable Natural Resources (Ibama).

\subsection{Forest replacement by Ibama and its decentralization to the environment State bodies}

Ibama was created based on Law 7,735/1989 (Brasil, 1989a). Its implementation occurred through the fusion of four Brazilian entities related to the environment, but with different approaches: the IBDF, the Environment Department (Sema), the Superintendence of Rubber (Sudhevea), and the Superintendence of Fishery (Sudepe). Thus, it became responsible for environmental management, articulation, coordination, execution, and control of the national environmental policy. In the same year, Law 7803/1989 was published, which amended Law 4,771/1965 and transferred the forest replacement responsibilities to the new body, at a federal level (Brasil, 1989b).

Ibama was created in a moment of great movement in the environmental scenario, two years after the launching of the Brundtland Report and one year after the publication of the New Brazilian Constitution (Machado, 2013). Initially, all actions were centralized in Ibama, which has an environmental nature aimed to preserve, according to Sabbag (2011), different from its predecessor, the IBDF, which was more focused on forest promotion. Since then, Ibama is more related to forest replacement monitoring. To correct this centralization of obligations and power, the following bodies were created: The Ministry of the Environment (MMA), in 1992, which, among other responsibilities was in charge of the replacement standardization; the Brazilian Forest Service (SFB), in 2006, aimed to expand forest cover; and the Chico Mendes Institute for Biodiversity Conservation (ICMBio), in 2007, the executor of the National System of Conservation Units (SNUC) (Moura, 2016).

Since its creation, the functions of Ibama were shared with State Environmental Agencies (OEMAs), according to the Federal Constitution of 1988, in which states were allowed to legislate concurrently on the environment. Thus, state laws regulated forest replacement such as Law 10,561/1991 in Minas Gerais and Law 10,155/1992 in Paraná. Through the law in
Minas Gerais, the legislator gave wide participation to the OEMAs technical staff, which began having responsibilities that were previously exclusive of Ibama:

Art. 18 - The registration of the activity and its annual renewal, at the IEF, are mandatory for physical or legal person who exploits, use, consume, transform, industrialize or commercialize, in any form, products, and by-products of the flora (Minas Gerais, 1991).

Since 1991, consumers of products from native forest in Minas Gerais have been obliged to have accreditation at the Forest State Institute (IEF). States with no similar state legislation should follow the specifications of the Law $7,803 / 1989$ and other Ibama regulations, planting within the state, preferably close to sources of consumption. However, legislations such as those of Minas Gerais and Paraná gave greater autonomy to the OEMA in managing and monitoring the activities.

The beginning of Ibama's activities was characterized by a significant use of forest raw material, both legal and illegal. According to Brito (1990), charcoal production, in 1988, used approximately 114 million $\mathrm{m}^{3}$ of wood, and data indicated that $78 \%$ of the total consumed came from native raw material. The use of native forests to obtain solid wood products, such as sawed wood and plywood, was also significant, accounting for 42 million $\mathrm{m}^{3}$ in 1990, of which $71.5 \%$ came from native sources (Abracave, 2001).

The Amazon Deforestation Estimation Project (Prodes) began monitoring deforestation in the Legal Amazon in 1988. In this year, the 5th highest rate of deforestation in the whole series was registered: $21,050 \mathrm{~km}^{2}$ (INPE, c2017). It was similar in the Atlantic Forest. Since the creation of Atlas monitoring, the highest rates of deforestation were recorded between 1985 and 1995, with more than 100 thousand hectares per year (Fundação SOS Mata Atlântica \& INPE, 2017).

The forest sector, in particular charcoal producers, was always criticized for its contribution to deforestation. However, much of the consumption made by these companies resulted from the expanding of agricultural and livestock frontiers. The areas were opened for alternative land use in the interior of the country, with livestock being the main cause of deforestation (Rivero et al., 2009). Thus, as long as the company uses forest raw material of legal origin, there is no problem regarding the transparency of how much it consumes, since by promoting new forest plantations it consequently promotes the sustainability of the sector.

The understanding of sustainability can vary, but its conception involves the aims and principles defined by society itself (Bellen, 2005). Thus, forest replacement can 
be considered as a mean that acts in parallel with the requirement of self-supply and an obligation of all large consumers using over 50 thousand $\mathrm{m}^{3}$ of logs, which must obey the Sustainable Supply Plan (PSS) (Sabbag, 2011). In 1990, any company consuming more than 12 thousand $\mathrm{m} 2$ of firewood or 4 thousand $\mathrm{m} 3$ of charcoal could use a maximum of $50 \%$ of native raw material, and until 1995, all of the company's consumption should come from their own forests (Brasil, 1989b).

Decree 97,628 and Ordinances 440, 441 and 710, all in 1989 , were the first regulations on forest replacement issued under Ibama's responsibility. They dealt differently with the replacement performed by large and small consumers; the late ones had no limit of consumption of native species of wood, established in the law, which allowed the collection by account in a fund similar to that collected by the INP and the IBDF, in which the company pays the environmental body so that it does the replacement planting. Ordinance 710 enabled the payment through forest promotion associations, which became widely used in several states (Sabbag, 2011).

The creation of the Forest Reforestation Associations (ARFs), by the ordinance 710/89-P, allowed the participation of non-profit civil organizations. The ARFs aimed to make the link between consumers of native raw material and rural producers who agreed to carry out forest replacement in their properties. The ARFs used forest replacement resources for environmental education and forest promotion, creating a new form of investment to small farmers, who saw forestry as a distant reality (Basso et al., 2012; Eisfeld et al., 2017).

The first initiative to create an Association for Forest Replacement occurred still in 1986 in the state of Santa Catarina, and later implemented in Rio Grande do Sul, Bahia and Minas Gerais (Sabbag, 2011). Within this new context, with less forest promotion since the period the IBDF was replaced by Ibama, these associations gained importance and became linked to state bodies.

During the 1990s, there were distinct scenarios between the two largest sectors of forest consumption. In 1995, the major consumers in the steel mill sector had not yet implemented self-supply and, thus, they continued using native raw material. In this year, the consumption accounted for 31 million $\mathrm{m} 3$ of charcoal; nearly half from native forests (Abracave, 2001). In contrast, the pulp industry already had self-supply, especially due to the competitive advantages of the production of eucalyptus short-fiber pulp, with higher productivity and lower costs when compared with competitors using long fiber in other countries (Hilgemberg \& Bacha, 2000; Montebello \& Bacha, 2013).

Native species such as "embaúba" (Cecropia sp.) and "bracatinga" (Mimosa bracatinga) have quality for pulp production (Barrichelo \& Foelkel, 1975). However, considering the incentives for plantations from the 1960s to the 1980s, when exotic species of the genus Eucalyptus were planted on a large scale, as well as the genetic improvement of these species, this genus has a significant advantage even in comparison with these local native species.

The first MMA Normative Instruction (NI) was published in 1996, which dealt with forest replacement in detail and determined a period of 10 years, until 2006, to achieve selfsupply, regulating the Forest Integrated Plan (PIF) (Brasil, 1996).

Consumption prevention was ineffective because illegal deforestation resulted in weak punishments when compared with the benefits gained. In this context, the Law of Environmental Crimes (No. 9,605/1998) became essential for imposing penal and administrative sanctions against conducts and activities harmful to the environment (Brasil, 1998). Before this law, an illegal deforestation could be a simple contravention punished with a fine. Hence, the crimes began to be weighted according to the severity of the impact, with punishments including fine and even imprisonment.

After the Law 9,605/1998, the OEMAs started to intervene more effectively and noncompliance with the Forest Code gave rise to administrative, civil and penal sanctions, which motivated the debates on the updating of the Forest Law (Brancalion et al., 2016). Regulations on the Law of Environmental Crimes dealt with specific plantings for forest replacement. From Decree $3,179 / 1999$, a fine of $R \$ 100$ to $R \$ 300$ was determined for the exploitation of forest replacement plantations (Art. 38) (Brasil, 1999); and Decree 6,514/2008, Art. 53, set the fine at $\mathrm{R} \$ 300$ for those who exploit forest replacement plantations, if they had no permission from the competent environmental body (Brasil, 2008).

Changes in the government's stance toward a more active monitoring and a more punitive legislation reflected on the consumption of native raw material, which declined. Near the year 2000, consumption of native charcoal accounted for $31 \%$ of the $26,220 \mathrm{~m} 3$, almost half of what was consumed in 1995 (Abracave, 2001).

Deforestation rates remained high. In Atlantic Forest areas, a deforestation rate of 89,000 ha/year (Fundação SOS Mata Atlântica \& INPE, 2017) was recorded. In the Legal Amazon, deforestation was approximately 1,681,900 ha/ year (INPE, c2017). These numbers combine legal and illegal deforestations, whereas those found in consumption yearbooks only show consumption of large companies of legal origin, which was restricted to reduce consumption and increase their areas of plantations.

In the decade after 2000, forest sector neither expanded spatially, considering the area had no significant increase 
since the end of the Tax Incentives Law for forest enterprises, nor increased the number of companies, which, actually declined as a result of the increased competitiveness within the sector. However, this sector increased in terms of competitiveness and the plantations in productivity. It also expanded the form of forest promotion performed by the companies themselves. Therefore, the market was strong and articulated in face of the legal restrictions on the use of native wood (Valverde et al., 2004).

In 2001, Brazil had already stood out as the 11th largest paper producer (Juvenal \& Mattos, 2002). In international trade, the country was characterized as the main exporter of eucalyptus short-fiber pulp, this development was mainly related to the success of public investment policies in the sector, not only in the plantations during tax incentives in the 1970s and the 1980s, but also in technology from the BNDES (Juvenal \& Mattos, 2002; Montebello \& Bacha, 2013).

Regarding the plantations, the planted area at the beginning of the decade was about 6 million hectares, mostly due to the significant advance in the period of tax incentives, between 1966 and 1988 (IBGE, 2007). The increase in area decelerated after the incentive period, increasing by 1.8 million hectares, totaling 7.8 million hectares IBÁ (2017).

This deceleration in forest plantation in new areas can also be observed with the decreased importance of the plantations in Brazil when compared with other countries. According to Moreira et al. (2017), based on FAO (2015) data, in 1990, Brazil had $2.83 \%$ of planted forests, but this number decreased to $2.67 \%$. In the same period, China increased its participation in the global area from $23.82 \%$ to $27.27 \%$.

According to Kengen (2001), after tax incentives for plantations in the 1980s, there were policies focused on production forests; in the early 1990s, the development of forest environmental policies for environmental conservation were the main focus; however, forest plantations for cutting were not encouraged by agricultural sector policies either. This scenario began to change in the late 2000s, when the National Forest Program was launched, but since the 1990s, forest production has stood out through the establishment of partnerships between the private sector and forest farmers.

Forest promotion reflected the results of investments and plantations in new areas, the steel sector supported promotion associations; however, the steel mills were still far from self-supply. Sabbag (2011), analyzing the number of forest plantations based on data from the main associations related to the steel sector, indicated a deficit in the plantation areas of 516,764 ha/year in this period; the area planted by the sector should be three times higher to cover all the demand. Even so, the deadline given by the NI 01/1996 to achieve self-supply ended in 2006 (Brasil, 1996).
In 2006, the MMA NI 06/2006 was also published and are still in force. This NI has no longer made available the payment through the "Account for Special Resources Application". As this option was extinguished, it only dealt with the fact that the body would use the financial resources left (Art. 34). Only the planting was allowed as a form of payment for the forest replacement, performed by the company itself (Art. 13) or by promotion (Art. 26). Since then, recovery plantations for Permanent Preservation Areas (PPAs) and Legal Reserve (LR) have been allowed to generate payment credits for replacement (Art. 15), which cannot be subjected to cutting, in the case of PPAs, this measure may be considered a distortion of the policy objective in generating forest stock for use. Also, the same NI defined that plantations of the Sustainable Supply Plan (PSS), related to self-supply, could not generate credits for forest replacement ( $\$ 2$ nd, Art. 4 th). Unlike the previous one, this NI sets no deadline to achieve $100 \%$ self-supply with products from planted forest (Brasil, 2006b).

Still in 2006, Decree 5,975/2006 was published, regulating among other articles, those referring to the forest replacement of the old Forest Code, Law 4771/1965. From this Decree (Art. 18), the OEMAs were required to have on the Internet a computerized record, reporting the credits and debits of the replacement, making available the proofs of transportation and storage of products and by-products, which would be implemented until 2007 (Brasil, 2006a).

In 2007, Ibama published the Execution Norm 03/2007, which defined the procedures for the exploitation of planted forests originating from tax incentives, as well as of those committed to Mandatory Forest Replacement (Brasil, 2007). The management of forest resources was considered the competence of the state environmental bodies to standardize the exploitation of forest resources in the Brazilian states. Some of them already had specific rules on forest replacement, being blamed for allowing the exploitation of native and planted forests; thus, they passed the responsibility for these plantations to the OEMAs.

According to Sabbag (2011), the initiative to decentralize forest replacement management was plausible and could provide more efficiency and effectiveness to the policy, which, as addressed by this author, was of little interest to the body and had few related servers, who had low capacity for an execution consistent with the legal needs of the forest replacement policy itself, which requires a technical inspection to prove and dispatch the report and due to credits according to the plantation development.

Then, the forest sector started a period of crisis. Political turmoil with heated discussions on the vote for a new Forest Code during a global economic crisis that affected the world 
financial system and had effects on the energy sources used (Vichi \& Mansor, 2009). As a result of the crisis, there was a chain reaction that reflected in several sectors of the world economy, showing the vulnerability and lack of preparation of the forest sector (Rezende et al., 2013).

The new Forest Law (No. 12,651/2012) is expected to be effective, making possible a more agile and integrated monitoring. For this purpose, it implemented the Rural Environmental Registry (Art. 29), in which all change in land use must be registered and updated by rural producers (Brasil, 2012). Regarding forest replacement, the new Forest Law (Art. 33) governs the obligation of forest replacement, in the same state the deforestation occurred (\$4th, Art. 33), to all consumers of forest raw material from the suppression of native vegetation ( $\$ 1$ st) (Brasil, 2012). The MMA NI $06 / 2006$ is still in force, as it details, adds and does not contradict the Forest Law.

Self-supply increased even after the use of species from natural forests was allowed, which may be related to combined measures that encourage forest production such as the fusion of the forest replacement with deforestation prevention measures, namely the Atlantic Forest Law (No. 11,428/2006), which prohibited the cutting and suppression according to stages of succession or functions of the forest, being more restricted than the Forest Law (Brasil, 2006c).

Consumption of wood products from native forest consequently decreased due to an annual retraction in the production of items from vegetal extractives. According to data from IBGE (2017), vegetal extraction from 2010 to 2016 decreased from 1.5 million tons to 0.5 million tons for charcoal, from about 38 million $\mathrm{m}^{3}$ to 25 million $\mathrm{m}^{3}$ for firewood, and only the consumption of wood in logs remained near 12 million $\mathrm{m}^{3}$; all of them obtained from natural forests.

Some factors are associated with the increased consumption of planted forests such as the increased society's awareness of the environment, the increase in socio-environmental restrictions, the demand for a high availability of forest products with better quality standards, the simplified environmental licensing, and the reduced production of raw material from native forests in the Caatinga, Cerrado, Atlantic Forest and also in the Amazon (Brasil, 2014).

Currently, the regularization of environmental liabilities, through the Rural Environmental Registry and the Environmental Regularization Program, is one of the projects assumed by the federal government, based on the new Forest Law. This is a courageous initiative with the challenge of recovering approximately 21 million hectares, of which $20 \%$ are located in riparian PPAs (Soares-Filho et al., 2014).

Based on NI 06/2006, the resources derived from forest replacement may be another input for the effective implementation of this regularization, mainly because the new legislation gave the LR a high economic importance, differently from the PPAs, in which forest replacement plantations are allowed but the cut and use of their resources are prohibited; unlike the purpose of the forest replacement policy. However, Sabbag (2011) considers that not even in LR replacement plantations should be allowed, because the resources must be used only for the promotion of new forest plantations, excluding degraded areas that should have been already covered with native vegetation.

Monitoring adjustments using currently available technology can increase the collection and balance so that certain uses of replacement remain even if they distort the essence of the policy, but contribute to environmental preservation. In this sense, the use of equations more appropriate to the diametric structure of the forest to be cut may be required (Lima \& Leão, 2013), in addition to a more robust transport control, considering it is the same model since the INP was in vigor (Sabbag, 2011).

According to Lima \& Bajay (2000), forest replacement is a mechanism that always had difficulties in practical application. Although it is legally and well prepared, its collection and monitoring are questioned. Freire (2009) addressed some faults in the use of transportation guides (waybills), Forest Origin Documents (DOF) used as command and control policy, which are still targets of fraud (Ibama, 2018). In the same study, this author pointed out a higher number of waybills, considering the requests for deforestation registered, to suppress larger volumes than those actually planted, which could cover the transportation of illegally native wood, resulting in the non-payment of the replacement.

Vianna et al. (2013) pointed out that the states of Mato Grosso, Minas Gerais, Pará, Rondônia, and São Paulo were some of those that legislated concurrently, creating new mechanisms and more specific rules such as the use of associations and plantations closer to the areas where there was consumption. According to the Execution Norm 03/2007, it is currently expected that all states continue performing the state collection, but it is important to demand transparency of payment and plantations resources and articulation between the state environmental bodies and the Ibama. There is also standardization on data transparency, Decree No. 5,795/2006.

\section{FINAL CONSIDERATIONS}

Forest replacement is a forest policy that contributed significantly to the current area of planted forests in Brazil, since by making companies consuming raw material from native forests plant areas equivalent to those they consumed, these plantations expanded, creating a market that also 
involves outsourced silviculturalists and forest replacement associations.

Most of the plantations were also related to the forest replacement in the period they had the most significant expansion with the tax incentives law was in force. This expansion would not have occurred without the involvement of part of the administrative public sector. Therefore, the role played by the IBDF is noteworthy, which distinguished from the INP for having a nationwide plantation strategy, acting differently from the current Ibama, with a more developmental and promoting stance.

The lack of transparency on forest replacement resources should be noted, not only from the OEMAs but also from Ibama, which could make available on the internet how much native raw material each state consumes, how much is paid for forest replacement, and what forms each company has chosen; however, this information is still unavailable.

The state itself, through the OEMAs, must also publicize information on how it manages the payment resources and what companies pass the obligation of performing the replacement to the OEMAs. Forest replacement is not a tax or collection tool; these payments should support measures and strategies to promote the Brazilian forest sector, stimulating the increase in forest production, improving the efficiency of fomentation and technical assistance, as well as supporting the creation of regional associations and cooperatives for the forest development in the country.

\section{ACKNOWLEDGEMENTS}

To the Graduate Program in Forestry of the Universidade Federal de Lavras (UFLA), the Graduate Program in Environmental and Forest Sciences of the Universidade Federal Rural do Rio de Janeiro (UFRRJ), and to the coworkers of the Núcleo de Estudos e Pesquisas em Planejamento Ambiental (NEPPA-UFLA).

\section{SUBMISSION STATUS}

Received: 22 Jan. 2018

Accepted: 28 Sept. 2018

Associate editor: Vanessa Maria Basso

(D) 0000-0003-3141-2262

\section{CORRESPONDENCE TO \\ Athila Leandro de Oliveira}

Universidade Federal Rural do Rio de Janeiro (UFRRJ), BR 465, km 7, CEP 23897-000, Seropédica, RJ, Brasil

e-mail: athila_mg@hotmail.com

\section{FINANCIAL SUPPORT}

This study was financed in part by the Coordenação de Aperfeiçoamento de Pessoal de Nível Superior (Capes) - Finance Code 001.

\section{REFERENCES}

Antunes J, Nascimento VS, Queiroz ZF. Narrativa crítica acerca do desenvolvimento sustentável: quais relações podemos estabelecer? Revista Eletrônica do Mestrado em Educação Ambiental 2017; 34(2): 57-75. 10.14295/remea.v34i2.6930

Associação Brasileira de Florestas Renováveis - Abracave. Anuário estatístico Abracave. Belo Horizonte; 2001.

Bacha CJC. A evolução do desmatamento no Brasil. Revista de Economia e Sociologia Rural 1995; 33(2): 111-135.

Bacha CJC. A expansão da silvicultura no Brasil. Revista Brasileira de Economia 1991; 45(1): 145-168.

Bacha CJC. O sistema agroindustrial da madeira no Brasil. Revista Econômica do Nordeste 2001; 32(4): 975-993.

Bacha CJC. O uso de recursos florestais e as políticas econômicas brasileiras: uma visão histórica e parcial de um processo de desenvolvimento. Estudos Econômicos 2004; 34(2): 393-426. 10.1590/ S0101-41612004000200007

Bacha CJC. Análise da evolução do reflorestamento no Brasil. Revista de Economia Agrícola 2008; 55(2): 5-24.

Banco Nacional de Desenvolvimento Econômico e Social - BNDES. A participação do sistema BNDES na evolução do setor de papel e celulose no Brasil. Rio de Janeiro; 1991.

Barrichelo LEG, Foelkel CEB. Utilização de madeiras de essências florestais nativas na obtenção de celulose: bracatinga (Mimosa bracatinga), embaúba (Cecropia sp), caixeta (Tabebuia cassinoides) e boleira (Joannesia princeps). IPEF 1975; (10): 43-56.

Basso VM, Jacovine LAG, Griffith JJ, Nardelli A, Alves RR, Souza AL. Programas de fomento rural no Brasil. Pesquisa Florestal Brasileira 2012; 32(71): 321-333. 10.4336/2012.pfb.32.71.321

Bellen HM van. Indicadores de sustentabilidade: uma análise comparativa. Rio de Janeiro: FGV Editora; 2005.

Borges LAC, Rezende JLP. Áreas protegidas no interior das propriedades rurais: a questão das APP e RL. Floresta e Ambiente 2011; 18(2): 210-222. 10.4322/floram.2011.040

Brancalion PH, Garcia LC, Loyola R, Rodrigues RR, Pillar VD, Lewinsohn TM. Análise crítica da lei de proteção da vegetação nativa (2012), que substituiu o antigo Código Florestal: atualizações e ações em curso. Natureza e Conservação 2016; 14(sup 1): e1-e16. 10.1016/j.ncon.2016.03.004

Brasil. Decreto n. 23.793, de 23 de janeiro de 1934. Diário Oficial da República Federativa do Brasil, Brasília, DF (1934 Mar. 21). Sec. 1: 5601.

Brasil. Decreto n. 79.046, de 27 de dezembro de 1976. Diário Oficial da República Federativa do Brasil, Brasília, DF (1976 Dec. 28). Sec. 1: 16775.

Brasil. Lei n. 6.938, de 31 de agosto de 1981. Diário Oficial da República Federativa do Brasil, Brasília, DF (1981 Sept. 2). Sec. 1: 16509.

Brasil. Constituição da República Federativa do Brasil. Diário Oficial da República Federativa do Brasil, Brasília, DF (1988 Oct. 5). 
Brasil. Lei n. 7.735, de 22 de fevereiro de 1989. Diário Oficial da República Federativa do Brasil, Brasília, DF (1989a Feb. 23). Sec. 1: 2729.

Brasil. Lei n. 7.803, de 18 de julho de 1989. Diário Oficial da República Federativa do Brasil, Brasília, DF (1989b July 20). Sec. 1: 12025.

Brasil. Instrução Normativa MMA n. 1, de 5 de setembro de 1996. Diário Oficial da República Federativa do Brasil, Brasília, DF (1996 Sept. 5).

Brasil. Lei n. 9.605, de 12 de fevereiro de 1998. Diário Oficial da República Federativa do Brasil, Brasília, DF (1998 Feb. 13). Sec. 1: 1.

Brasil. Decreto n. 3.179, de 21 de setembro de 1999. Diário Oficial da República Federativa do Brasil, Brasília, DF (1999 Sept. 22). Sec. 1: 1.

Brasil. Decreto n. 5.795, de 5 de junho de 2006. Diário Oficial da República Federativa do Brasil, Brasília, DF (2006a June 6). Sec. 1: 1.

Brasil. Instrução Normativa MMA n. 6, de 15 de dezembro de 2006. Diário Oficial da República Federativa do Brasil, Brasília, DF (2006b Dec. 18). Sec. 1.

Brasil. Lei n. 11.428, de 22 de dezembro de 2006. Diário Oficial da República Federativa do Brasil, Brasília, DF (2006c Dec. 26).

Brasil. Norma de Execução n. 3, de 2 de maio de 2007. Diário Oficial da República Federativa do Brasil, Brasília, DF (2007 May 2).

Brasil. Decreto n. 6.514, de 22 de julho de 2008. Diário Oficial da República Federativa do Brasil, Brasília, DF (2008 July 23). Sec. 1: 1.

Brasil. Lei n. 12.651, de 25 de maio de 2012. Diário Oficial da República Federativa do Brasil, Brasília, DF (2012 May 28).

Brasil. Florestas plantadas: bases para a política nacional. Brasília, DF: SAE/PR; 2014.

Brito JO. Carvão vegetal no Brasil: gestões econômicas e ambientais. Estudos Avançados [Internet] 1990 [cited 2016 Mar. 29]; 4(9); 221227. Available from: http://bit.ly/2qfLACx

Câmara Setorial de Silvicultura - CSS. Agenda estratégica do setor de florestas plantadas [Internet]. Brasília, DF; 2009 [cited 2017 June 7]. Available from: http://bit.ly/36phI7o

Campos I, Chagas RC. Reflorestamento versus floresta nativa: tendências e desafios à siderurgia na Amazônia. Papers do NAEA 2012; 295: 1-18.

Eisfeld RL, Socher LG, Ribeiro CC. Modelo de fomento florestal nas instituições estaduais nos estados do Sul, São paulo e Minas Gerais. Biofix 2017; 2(2): 1-9. 10.5380/biofix.v2i2.53230

Fonseca AA. Origens do desenvolvimento nacional. Tempo 2008; 13(25): 216-223. 10.1590/S1413-77042008000200010

Food and Agriculture Organization of the United Nations - FAO. Global forest resources assessment 2015: desk reference. Rome: United Nations; 2015.

Freire RG. Reposição florestal: mecanismo econômico para a conservação do bioma cerrado? [thesis] Brasília, DF: Universidade de Brasília; 2009.

Fundação SOS Mata Atlântica, Instituto Nacional de Pesquisas Espaciais - INPE. Atlas dos remanescentes florestais da Mata Atlântica: período 2015-2016. São Paulo: Arcplan; 2017.

Furtado TS, Ferreira JC, Brand MA, Muñiz GIB, Quirino WF. Mapeamento da frequência de uso e características da biomassa florestal utilizada para geração de energia em Lages, SC. Ciência Florestal 2012; 22(4): 795-802. 10.5902/198050987560

Gelis Filho A. Análise comparativa do desenho normativo de instituições reguladoras do presente e do passado. Revista de Administração Pública 2006; 40(4): 589-613. 10.1590/S003476122006000400005

Gomes Neto JF, Léda RLM. Mercado florestal brasileiro: uma análise sobre as políticas públicas e perspectivas de cenário econômico. Cadernos de Ciências Sociais Aplicadas 2009; 4(5-6): 265-278.

Gonçalves MT. A formação da economia das plantações florestais nos Vales do Rio Doce e do Aço de Minas Gerais (1940-2000): notas sobre história econômica e ambiental de uma região. In: Seminário sobre a Economia Mineira [Internet]; 2006, Diamantina. Belo Horizonte: UFMG; 2006 [cited 2016 Oct. 20]. Available from: http://bit.ly/322kkF7

Griggs D, Stafford-Smith M, Gaffney O, Rockström J, Öhman MC, Shyamsundar P et al. Sustainable development goals for people and planet. Nature 2013; 495: 305-307. 10.1038/495305a

Hilgemberg EM, Bacha CJC. As pressões ambientais e as alterações na demanda e oferta mundial de celulose. Pesquisa e Debate 2000; 11(18): 67-92.

Hilgemberg EM, Bacha CJC. A evolução da indústria brasileira de celulose e sua atuação no mercado mundial. Análise Econômica 2001; 19(36): 145-164. 10.22456/2176-5456.10679

Hoeflich VA, Silva JA, Santos AJ. Política florestal: conceitos e princípios para a sua formulação e implementação [Internet]. Colombo: Embrapa Florestas; 2007 [cited 2017 June 11]. Available from: http://bit.ly/2WwJB92

Indústria Brasileira de Árvores - IBÁ. Relatório 2017 [Internet]. São Paulo; 2017 [cited 2017 June 10]. Available from: http://bit. ly/2C54hf7

Instituto Brasileiro de Geografia e Estatística - IBGE. Censo agropecuário 1920/2006: até 1996, dados extraídos de estatísticas do século XX [Internet]. Rio de Janeiro; 2007 [cited 2017 June 15]. Available from: https://goo.gl/VYykYw

Instituto Brasileiro de Geografia e Estatística - IBGE. Produção da extração vegetal e da silvicultura 2016 [Internet]. Rio de Janeiro; 2017 [cited 2018 June 15].v. 31. Available from: https://goo.gl/RBKGQ7

Instituto Brasileiro do Meio Ambiente e dos Recursos Naturais Renováveis - Ibama. Ibama realiza maior apreensão de madeira ilegal da Amazônia em SP [Internet]. 2018 [cited 2018 June 12]. Available from: https://goo.gl/wmEPtP

Instituto Nacional de Pesquisas Espaciais - INPE. Taxas de desmatamento anuais e variações relativas da Amazônia Legal Brasileira: taxa anual de desmatamento entre 1998-2007 (km2/ ano) [Internet]. c2017 [cited 2017 June 12]. Available from: http:// bit.ly/33aydSM

Instituto Nacional do Pinho - INP. Resolução n. 101, de 19 de dezembro de 1949. In: INP. Anuário brasileiro de economia florestal. Rio de Janeiro; 1950.

Juvenal TL, Mattos RLG. BNDES 50 anos: histórias setoriais: o setor de celulose e papel. Rio de Janeiro; 2002.

Kengen $S$. A política florestal brasileira: uma perspectiva histórica. Série Técnica IPEF 2001; 14(34): 18-34. 
Lima CR, Bajay SV. A reposição florestal obrigatória e o planejamento energético regional. Revista Baiana de Tecnologia 2000; 1(15): 140-144.

Lima JPC, Leão JRA. Dinâmica de crescimento e distribuição diamétrica de fragmentos de florestas nativa e plantada na Amazônia sul ocidental. Floresta e Ambiente 2013; 20(1): 70-79. 10.4322/ floram. 2012.065

Lopes AE, Rocha ACT, Lima AO, Antunes DA, Ferrão EMG, Oliveira Júnior AF. Do ecodesenvolvimento ao desenvolvimento sustentável: a trajetória de conflitos e desafios para o meio ambiente. ForScience 2017, 5(2): e00314. 10.29069/forscience.2017v5n2.e314

Machado, PAL. Direito ambiental brasileiro. 21st ed. São Paulo: Malheiros; 2013.

Madeira Filho W. Colonização verde: estratégias da política florestal após o Protocolo de Quioto. In: Madeira Filho W. Direito e justiça ambiental. Niterói: PPGSD UFF; 2002. p. 217-237.

Martins ML. A política florestal, os negócios de lenha e o desmatamento: Minas Gerais, 1890-1950. Halac 2011; 1 (1): 29-54.

Medeiros R. Evolução das tipologias e categorias de áreas protegidas no Brasil. Ambiente e Sociedade 2006; 9(1): 41-64. 10.1590/S1414753X2006000100003

Minas Gerais. Lei n. 10.561, de 27 de dezembro de 1991. Diário do Executivo, Belo Horizonte (1991 Dec. 28)

Minas Gerais. Lei n. 20.922, de 16 de outubro de 2013. Diário do Executivo, Belo Horizonte (2013 Oct. 17).

Montebello AES, Bacha CJC. Análise do processo de configuração desigual do setor de celulose e papel no Brasil. Pesquisa e Debate 2013; 23(44): 267-294.

Monteiro MA. Siderurgia e carvoejamento na Amazônia: drenagem energético-material e pauperização regional. Belém: UFPA/ETFPA; 1998.

Moreira JMM, Simioni FJ, Oliveira EB. Importância e desempenho das florestas plantadas no contexto do agronegócio brasileiro. Floresta 2017; 47(1): 85-94. 10.5380/rf.v47i1.47687

Moura AMM. Trajetória da política ambiental federal do Brasil. In: Moura AMM, editor. Governança ambiental no Brasil: instituições, atores e políticas públicas. Brasília, DF: Ipea; 2016. p. 13-44.

Norder LA. As propostas de restauração de florestas nativas no Brasil (1912-1944). História Revista 2017; 22(2): 121-143. 10.5216/ hr.v22i2.43091
Pereira HS. Estado actual de la información sobre instituciones forestales. In: FAO. Información por el desarrollo forestal sostenible: estado de la información forestal en Brasil. FAO: Monografía de Países; 2002. v. 3. p. 40-74.

Rezende AM, Silva ML, Soares NS, Moura AD, Mendes TF, Costa CB. Crescimento econômico apesar de lento, irradia-se positivamente para os negócios florestais [Internet]. Belo Horizonte: CI Florestas; 2013 [cited 2017 June 14]. Available from: http://bit.ly/2PDNwPW

Rivero S, Almeida O, Ávila S, Oliveira W. Pecuária e desmatamento: uma análise das principais causas diretas do desmatamento na Amazônia. Nova Economia 2009; 19(1): 41-66. 10.1590/S010363512009000100003

Sabbag SC. Reposição florestal: caminho para o desenvolvimento sustentável da silvicultura tropical [thesis]. Brasília, DF: Universidade de Brasília; 2011

Silva JBA. Lembranças e apontamentos do governo provizorio da província de S. Paulo para os seus deputados mandadas publicar por ordem de Sua Alteza Real, o príncipe regente do Brasil [Internet]. Rio de Janeiro: Typographia Nacional; 1821 [cited 2017 jun 10]. Available from: https://goo.gl/AYylaq

Soares LSV, Aguiar AAML. Os limites da obrigação da reposição florestal e o seu alcance aos novos proprietários: inaplicabilidade da obrigação in propter rem à imóveis com supressão vegetal preexistente. Revista de Direito Ambiental e Socioambientalismo 2017; 3(2): 173-187. 10.26668/IndexLawJournals/2525-9628/2017. v3i 2.3767

Soares-Filho B, Rajão R, Macedo M, Carneiro A, Costa W, Coe M et al. Cracking Brazil's forest code. Science 2014; 344(6182): 363-364. 10.1126/science.1246663

Sociedade Brasileira de Silvicultura - SBS. Fatos e números do Brasil florestal. São Paulo: SBS; 2008.

Valverde SR, Soares NS, Silva ML, Jaconvine LAG, Neiva SA. O comportamento do mercado da madeira de eucalipto no Brasil. Biomassa e Energia 2004; 1(4): 393-403.

Vianna ALM, Barros PC, Arruda AN, Moreira N, Koury CG, Nogueira O. Lei de reposição florestal no estado do Amazonas: potencialidades para o setor florestal. Manaus: Idesam; 2013.

Vichi FM, Mansor MTC. Energia, meio ambiente e economia: o Brasil no contexto mundial. Química Nova 2009; 32(3): 757-767. 10.1590/S0100-40422009000300019 